\title{
Phytoprotection
}

\section{Dehydrated pork manure by-product: effect of a chitosan amendment on bacterial community and common scab incidence}

\section{Sous-produit déshydraté du purin de porc : effet d'un amendement de chitosane sur la communauté bactérienne et l'incidence de la gale commune}

\author{
Julie Roy, Pierre J. Lafontaine, Rock Chabot et Carole Beaulieu
}

Volume 90, numéro 3, 2009

URI : https://id.erudit.org/iderudit/045779ar

DOI : https://doi.org/10.7202/045779ar

Aller au sommaire du numéro

Éditeur(s)

Société de protection des plantes du Québec (SPPQ)

ISSN

0031-9511 (imprimé)

1710-1603 (numérique)

Découvrir la revue

Citer cet article

Roy, J., Lafontaine, P. J., Chabot, R. \& Beaulieu, C. (2009). Dehydrated pork manure by-product: effect of a chitosan amendment on bacterial community and common scab incidence. Phytoprotection, 90(3), 107-115.

https://doi.org/10.7202/045779ar

\section{Résumé de l'article}

Un amendement en chitosane a modifié la composition de la communauté microbienne associée à un sous-produit déshydraté de fumier de porc. Le produit amendé (biosolide PC) contenait un nombre de bactéries anaérobies inférieur à celui du produit non amendé (biosolide P). Le chitosane a aussi réduit de façon significative la population fongique. Une banque de gènes de l'ARNr $16 \mathrm{~S}$ construite à partir de l'ADN extrait de la communauté bactérienne associée aux biosolides $\mathrm{P}$ et $\mathrm{PC}$ a révélé que les ordres bactériens

Xanthomonodales, Pseudomonadales, Enterobacteriales, Burkholderiales, Actinomycetales, Bacillales, Clostridiales et Lactobacillales se trouvaient dans les deux types de biosolides. Les bactéries du genre Stenotrophomonas étaient les plus abondantes dans les deux types de biosolides. L'addition de chitosane a toutefois induit des changements dans la population de quelques genres de bactéries. Par exemple, les clones transportant un gène d'ARNr 16S

correspondant au genre Bacillus doublaient dans le biosolide PC. Dans des essais en champs entrepris dans le but de tester leur effet sur l'incidence de la gale commune, les biosolides P et PC ont été appliqués comme traitement des semences de pomme de terre. Le biosolide $\mathrm{P}$ a augmenté l'incidence de la maladie par un facteur de 1,33 et de 2,85 dans deux expériences indépendantes. Toutefois, quand le chitosane était ajouté au traitement de semences, l'effet stimulant du biosolide P sur la gale commune était aboli. 


\title{
Dehydrated pork manure by-product: effect of a chitosan amendment on bacterial community and common scab incidence
}

\author{
Julie Roy ${ }^{1}$ Pierre J. Lafontaine ${ }^{2}$, Rock Chabot $^{3}$, and Carole Beaulieu $\bowtie$
}

Received 2010-08-06; accepted 2010-12-14

PHYTOPROTECTION 90 : 107-115

Chitosan amendment modified the composition of a microbial community associated with dehydrated pork manure by-product. The amended product (biosolid PC) contained a lower number of anaerobic bacteria than the non-amended product (biosolid P). Chitosan also significantly reduced the fungal population. A 16S rRNA gene bank constructed from DNA extracted from the bacterial community associated with both $\mathrm{P}$ and $\mathrm{PC}$ biosolids revealed that bacterial orders Xanthomonodales, Pseudomonadales, Enterobacteriales, Burkholderiales, Actinomycetales, Bacillales, Clostridiales and Lactobacillales were found in both biosolids. Bacteria from the Stenotrophomonas genus were abundant in both biosolids. However, the addition of chitosan appeared to induce changes in the population of some bacterial genera. For example, clones carrying a 16S rRNA gene corresponding to the Bacillus genus were doubled in biosolid PC. In field trials carried out to test their effect on common scab incidence, biosolids $\mathrm{P}$ and PC were applied as potato seed treatment. Biosolid P increased disease incidence by a factor of 1.33 and 2.85 in two independent experiments. However, when chitosan was added to the seed treatment, the stimulating effect of biosolid P on common scab was cancelled out.

Keywords: 16S rRNA gene, liquid manure, potato, Streptomyces scabiei, Streptomyces scabies.

[Sous-produit déshydraté du purin de porc: effet d'un amendement de chitosane sur la communauté bactérienne et l'incidence de la gale commune]

Un amendement en chitosane a modifié la composition de la communauté microbienne associée à un sous-produit déshydraté de fumier de porc. Le produit amendé (biosolide PC) contenait un nombre de bactéries anaérobies inférieur à celui du produit non amendé (biosolide $\mathrm{P}$ ). Le chitosane a aussi réduit de façon significative la population fongique. Une banque de gènes de I'ARNr 16S construite à partir de I'ADN extrait de la communauté bactérienne associée aux biosolides $\mathrm{P}$ et PC a révélé que les ordres bactériens Xanthomonodales, Pseudomonadales, Enterobacteriales, Burkholderiales, Actinomycetales, Bacillales, Clostridiales et Lactobacillales se trouvaient dans les deux types de biosolides. Les bactéries du genre Stenotrophomonas étaient les plus abondantes dans les deux types de biosolides. L'addition de chitosane a toutefois induit des changements dans la population de quelques genres de bactéries. Par exemple, les clones transportant un gène d'ARNr 16S correspondant au genre Bacillus doublaient dans le biosolide PC. Dans des essais en champs entrepris dans le but de tester leur effet sur l'incidence de la gale commune, les biosolides $\mathrm{P}$ et PC ont été appliqués comme traitement des semences de pomme de terre. Le biosolide $\mathrm{P}$ a augmenté I'incidence de la maladie par un facteur de 1,33 et de 2,85 dans deux expériences indépendantes. Toutefois, quand le chitosane était ajouté au traitement de semences, l'effet stimulant du biosolide P sur la gale commune était aboli.

Mots clés: gène d'ARNr 16S, lisier, pomme de terre, Streptomyces scabiei, Streptomyces scabies.

1. Centre SĖVE, Département de biologie, Université de Sherbrooke, Sherbrooke (Québec), Canada J1K 2R1; corresponding author e-mail: carole.beaulieu@usherbrooke.ca

2. CIEL-Centre de valorisation des plantes, L'Assomption (Québec), Canada J5W 4M9

3. Pro Gestion MEC, Québec (Québec), Canada G2C 2J6 


\section{INTRODUCTION}

Animal manure is commonly used in agriculture as a fertilizer to improve soil fertility and plant productivity (Schröder 2005). Some studies have shown that manure as well as some other types of organic matter may reduce the severity and incidence of some plant diseases (Hadar et al. 1992; Huber and Watson 1970). Although the mechanisms of disease suppression associated with organic matter are not fully understood, it has been postulated that such material could affect both the viability and survival of plant pathogens through the restriction of available nutrients, the release of antimicrobial substances (Bailey and Lazarovits 2003), or the modification of soil properties (Keinath and Loria 1989; Pennypacker 1989). In addition, organic amendments might stimulate the growth of microbial populations antagonistic to pathogens (Vruggink 1970). Several organisms antagonistic to soilborne pathogens have also been isolated from suppressive composts (Kwok et al. 1987; Labrie et al. 2001), suggesting that microorganisms colonizing organic matter might be at least partly responsible for the disease suppression effect attributed to those products.

Although the suppressive effect of animal manure has been demonstrated for several plant diseases (Gorissen et al. 2004; Osunlaja 1990), manure amendment is usually not recommended in potato fields. Some authors have reported that soil amendment with animal manure induced an increase in common scab incidence (Blodgett 1940), a disease caused by Streptomyces scabies (Lambert and Loria 1989) that results in important economic losses for the potato industry in Canada (Hill and Lazarovits 2005). However, the relationship between common scab incidence and manure application is still controversial. While some studies have established a correlation between manure application and common scab symptoms (Hooker 1981), other works have suggested that soil amendment with cattle and chicken manure reduced the incidence of this disease (Conn and Lazarovits 1999).

Other organic materials have proven to be efficient in reducing common scab of patato. For example, soil amendment with shrimp shells (Vruggink 1970) or with composts containing chitinous material (Côté et al. 2001) reduced common scab incidence. Beauséjour et al. (2003) also showed that a potato seed treatment with chitosan, a natural polymer known to inhibit the growth of several bacteria (Kurita 2006; Liu et al. 2001), could decrease the incidence of common scab of potato.

Here, we study a pork manure by-product. The technology used to obtain this product was developed by Envirogain (Saint-Romuald, QC, Canada). The aims of this study were to determine the effect of a chitosan amendment on the microbial community associated with the pork manure by-product and the effect of both amended and non-amended pork manure by-products on common scab of potato.

\section{MATERIALS AND METHODS}

\section{Preparation of biosolid P and biosolid PC}

Biosolid $P$ was obtained as followed. Swine manure (Ferme CEPP, Saint-Anselme, QC, Canada) was first collected and homogenized. The first step in the manure treatment consisted of a physical separation of the liquid and solid components of pork manure. Liquid manure was detoxified in an aerobic-anoxic bioreactor that produces alternatively nitrificationdenitrification conditions for a hydrolic retention time of more than $30 \mathrm{~d}$ at $35-40^{\circ} \mathrm{C}$. Polyacrylamide (LPM Technologies Inc., Saint-Nicolas, QC, Canada), a flocculating agent, was added and mixed with the treated liquid manure at a concentration of $20 \mathrm{~g} \mathrm{~m}^{-3}$. The mixture was allowed to settle during $60 \mathrm{~min}$. The biological mud was then filtered and mixed with the solid components recovered in the first step of the biological treatment. This mixture was dried at $50^{\circ} \mathrm{C}$ for $24 \mathrm{~h}$ (93\% of dry matter) to obtain biosolid P. Biosolid PC was obtained by adding non-sterile chitosan (Marinard Biotech, Rivière-au-Renard, OC, Canada) to biosolid P (1 g $100 \mathrm{~g}^{-1}$ of biosolid) after the drying step. Following this addition, biosolid PC was stored at room temperature for $10 \mathrm{~d}$.

\section{Microbial cell extraction}

Microbial cells were extracted from $3 \mathrm{~g}$ of biosolid as previously described (Prévost et al. 2006). Briefly, a biosolid sample was added to $100 \mathrm{~mL}$ of sterile sodium pyrophosphate $0.1 \%$ (w:v) for $30 \mathrm{~min}$ at room temperature. This suspension was centrifuged at $55 \mathrm{~g}$ for $10 \mathrm{~min}$. The resulting supernatant was centrifuged again at $3500 \mathrm{~g}$ for $15 \mathrm{~min}$ to recover microbial cells.

\section{Enumeration of total bacteria, actinomycetes and fungi in biosolids}

Microbial cells were extracted from $3 \mathrm{~g}$ of biosolid as described above and were dispersed in $10 \mathrm{~mL}$ of $0.85 \% \mathrm{NaCl}$. Bacteria, actinomycetes and fungi were enumerated by dilution plating on Nutrient Agar (NA; Difco Laboratories, Detroit, MI, USA) supplemented with $0.3 \mu \mathrm{g} \mathrm{mL}^{-1}$ cycloheximide and $0.05 \mu \mathrm{g} \mathrm{mL}^{-1}$ nystatin, Actinomycetes Isolation Agar (AIA; Difco Laboratories, Detroit, MI, USA) supplemented with the same antibiotics, and Potato Dextrose Agar (PDA; Difco Laboratories, Detroit, MI, USA) supplemented with $10 \mu \mathrm{g} \mathrm{mL}^{-1}$ penicillin $\mathrm{G}, 0.1 \mu \mathrm{g} \mathrm{mL}^{-1}$ ampicilin and $0.1 \mu \mathrm{g} \mathrm{mL}^{-1}$ kanamycin. NA, PDA and AIA plates were incubated at $28^{\circ} \mathrm{C}$ for 3,7 and $8 \mathrm{~d}$, respectively. Anaerobic bacteria count was also determined on NA plates supplemented with $0.3 \mathrm{mg} \mathrm{mL}^{-1}$ cycloheximide and $0.05 \mu \mathrm{g} \mathrm{mL}^{-1}$ nystatin, but the incubation was carried out in anaerobic jars for $3 \mathrm{~d}$. All counts were carried out on four biosolid samples and were expressed as colony forming-unit (CFU) per $\mathrm{g}$ of dried biosolid.

\section{DNA extraction from biosolid microorganisms}

Microbial cells were recovered as described above and their DNA was extracted using the Kutchma et al. (1998) protocol modified as follows. Microbial cells $(50 \mathrm{mg}$ ) were washed in $1 \mathrm{~mL}$ of TE $(50 \mathrm{mM}$ Tris- $\mathrm{HCl}$, $20 \mathrm{mM}$ EDTA, pH 8.0) and the suspension was centrifuged for $4 \mathrm{~min}$ at $16000 \mathrm{~g}$. The microbial pellet was resuspended in $1 \mathrm{~mL}$ of ice-cold acetone and 
incubated on ice for $5 \mathrm{~min}$. The acetone was then carefully removed by aspiration and the cells were lyzed with $500 \mu \mathrm{L}$ of TE containing $1 \mathrm{mg} \mathrm{mL}^{-1}$ lysozyme (Sigma-Aldrich, Oakville, ON, Canada). SDS (sodium dodecyl sulphate) and $\mathrm{NaCl}$ were added to the lysozyme solution to a final concentration of $1.5 \%$

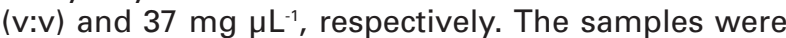
submitted to a freeze-thaw cycle $\left(-70^{\circ} \mathrm{C} / 65^{\circ} \mathrm{C}\right)$ and then they were centrifuged at $16000 \mathrm{~g}$ for $5 \mathrm{~min}$ to pellet cell debris. DNAse-free RNase (Ribonuclease A; Sigma-Aldrich, Oakville, ON, Canada) was added to the supernatant at a final concentration of $200 \mathrm{\mu g} \mathrm{mL}^{-1}$. The extracted DNA was purified by a phenol:chloroform:isoamyl alcohol (25:24:1) extraction, precipitated with ethanol $95 \%$ and washed with ethanol $70 \%$. DNA was finally dissolved in $300 \mu \mathrm{l}$ TE (10 mM Tris- $\mathrm{HCl}, 1 \mathrm{mM}$ EDTA, $\mathrm{pH}$ 8.0) and stored at $20^{\circ} \mathrm{C}$.

\section{PCR amplification of the 16s rRNA gene, cloning and sequencing}

PCR amplification was carried out by using the universal primers for the 16s rRNA gene: BSF8/20 (5'-AGAGTTTGATCCTGGCTCAG-3') and BSR1541/20 (5-'AAGGA GGTGATCCAGCCGCA-3') (Whitehead and Cotta 2004). Amplification was performed in $50 \mu \mathrm{L}$ total volume of a reaction mixture containing $\sim 20 \mathrm{ng}$ of biosolid DNA, $0.5 \mu \mathrm{L}$ of Taq DNA polymerase (Amersham Biosciences, Piscataway, NJ, USA), an appropriate dilution of the manufacturer's buffer, each deoxynucleoside triphosphate at a concentration of $250 \mu \mathrm{M}$, each primer at a concentration of $0.2 \mathrm{pmol} \mu \mathrm{L}^{-1}$, and $5 \mu \mathrm{L}$ of DMSO. DNA amplification was performed with a T-personal thermocycler (Whatman Biometra, Goettingen, Germany) and the following program was used: one step of initial denaturation at $95^{\circ} \mathrm{C}$ for $10 \mathrm{~min}$, followed by 34 cycles of denaturation at $94^{\circ} \mathrm{C}$ for $1 \mathrm{~min}$, annealing at $53^{\circ} \mathrm{C}$ for $90 \mathrm{~s}$, and extension at $72^{\circ} \mathrm{C}$ for $90 \mathrm{~s}$. This was followed by a final step of extention consisting of incubation at $72^{\circ} \mathrm{C}$ for $10 \mathrm{~min}$. Amplicons were migrated in a $1.0 \%$ agarose gel and electropheresis was carried out in Tris-acetate-EDTA buffer (Sambrook and Russel 2001). Bands of about 1500 pb were excised from the gel and DNA was recovered using GFX PCR DNA and Gel Band Purification kit (Amersham Biosciences, Piscataway, NJ, USA). The 16s rDNA library was constructed by cloning the purified amplification products into vector pCR 2.1 (Invitrogen Corporation, Carlsbad, CA, USA) using a vector/insert ratio of 1:1, and the resulting plasmids were transformed into OneShot ${ }^{\circledR} I N V_{\alpha} \mathrm{F}^{\prime}$ chemically competent Escherichia coli (Migula) Castellani \& Chalmers cells (Invitrogen Corporation, Carlsbad, CA, USA). The transformants were plated onto Luria-Bertani (LB) plates containing $100 \mu \mathrm{g} \mathrm{mL}^{-1}$ ampicilin and $1 \mathrm{mg} \mathrm{mL}^{-1} \mathrm{X}$-gal (5-bromo$\alpha$-chloro-3-indol- $\beta$-D-galactopyraniside). White colonies were randomly picked up, grown in LB medium containing $100 \mu \mathrm{g} \mathrm{mL}^{-1}$ ampicilin, and their plasmids were isolated by using the Gene Elute ${ }^{\mathrm{TM}}$ Plasmid Miniprep Kit (Sigma-Aldrich, Oakville, ON, Canada). Plasmids carrying inserts were digested with EcoRI. One hundred clones from each biosolid were conserved and their inserts were sequenced at the Quebec Innovation Centre (Montréal, QC, Canada).

\section{Phylogenetic analysis}

The 16S rRNA gene sequences of our clones were compared with those from the RDP database using the BLAST program (Madden et al. 1996) from NCBI. The chimers check program from the Ribosome Database Project II site (Maidak et al. 2000) was used to detect inserts consisting of chimera. The partial 16S rDNA sequences obtained in this study were deposited in the GenBank database under accession numbers DQ374451 through DQ374468.

\section{Field experiments}

Trials were conducted in fields naturally infested with common scab-inducing pathogens as previously described (Beauséjour et al. 2003). The first site was located in L'Assomption (QC, Canada) and consisted of loamy soil. The second was located in Lavaltrie (QC, Canada) and consisted of sandy soil. Potatoes (Solanum tuberosum L. cv. Shepody) were grown in the L'Assomption and Lavaltrie sites in 2004 and 2005 , respectively.

Band fertilisation with $\mathrm{NH}_{4} \mathrm{NO}_{3}, \mathrm{P}_{2} \mathrm{O}_{5}$ and $\mathrm{K}_{2} \mathrm{O}$ (N-PK) in 2004 at L'Assomption was 160,120 and $190 \mathrm{~kg}$ $\mathrm{ha}^{-1}$, respectively. Split application of $\mathrm{NH}_{4} \mathrm{NO}_{3}$ at 100 $\mathrm{kg} \mathrm{ha}^{-1}$ and $60 \mathrm{~kg} \mathrm{ha}^{-1}$ was carried out at planting and 7 wk later, respectively. Band N-P-K fertilisation in 2005 at Lavaltrie was 180,100 and $200 \mathrm{~kg} \mathrm{ha}^{-1}$. Application of $\mathrm{NH}_{4} \mathrm{NO}_{3}$ and $\mathrm{P}_{2} \mathrm{O}_{5}$ was split. $\mathrm{NH}_{4} \mathrm{NO}_{3}$ was applied at planting and $7 \mathrm{wk}$ later at 120 and $60 \mathrm{~kg} \mathrm{ha}^{-1}$, respectively, and $\mathrm{P}_{2} \mathrm{O}_{5}$ was applied at 120 $\mathrm{kg} \mathrm{ha}^{-1}$ and $80 \mathrm{~kg} \mathrm{ha}^{-1}$, respectively. An experimental plot $(7.5 \mathrm{~m} \times 4.0 \mathrm{~m})$ consisted of four rows planted with 26 seed tubers. Plots were set up as randomized complete blocks with four replicates, and were sepa-

Table 1. Counts of bacteria, actinomycetes and fungi from biosolids $P$ and PC

\begin{tabular}{|c|c|c|c|c|}
\hline \multirow{3}{*}{$\begin{array}{l}\text { Manure } \\
\text { by-product }\end{array}$} & \multicolumn{4}{|c|}{$\begin{array}{c}\text { Counts } \\
{\text { (CFU } \mathrm{g}^{-1} \text { of biosolid) }}^{1}\end{array}$} \\
\hline & \multicolumn{2}{|c|}{ Bacteria $^{2}$} & \multirow{2}{*}{ Actinomycetes } & \multirow{2}{*}{ Fungi } \\
\hline & Aerobic & Anaerobic & & \\
\hline Biosolid P & $4.1 \times 10^{5} \mathrm{a}$ & $2.0 \times 10^{4} \mathrm{a}$ & $7.5 \times 10^{2} a$ & $1.0 \times 10^{3} \mathrm{a}$ \\
\hline Biosolid PC & $3.5 \times 10^{5} a$ & $1.1 \times 10^{4} b$ & $7.0 \times 10^{2} a$ & $7.5 \times 10^{2} \mathrm{~b}$ \\
\hline
\end{tabular}

${ }^{1}$ CFU: colony-forming unit.

${ }^{2}$ Within a column, data followed by the same letter do not differ significantly $(P>0.05$, LSD test). 
rated by two flanking rows of potatoes. A potato seed treatment was carried out at plantation. Each potato seed was covered with $2 \mathrm{~g}$ of biosolid P, biosolid PC or talc. At harvest, all potato tubers were harvested and potato yield was measured for each plot. One hundred tubers from each plot were used to evaluate disease incidence, which was determined as the number of infected tubers covered by scab lesions on more than $5 \%$ of their surface over the total number of tubers.

\section{Statistical analyses}

Statistical analyses were carried out using the GLM procedure of the SAS 9.1 statistical package. Most sets of data requiring statistical analyses were performed with one-way ANOVAs followed by LSD tests. A $\chi^{2}$ test was carried out to compare disease incidence between treatments.

\section{RESULTS}

\section{Bacteria, actinomycetes and fungi counts in biosolids $\mathbf{P}$ and $\mathrm{PC}$}

The main microbial groups found in the biosolids were enumerated on culture media. Chitosan amendment brought slight changes in the microflora composition of biosolid P. Chitosan-amended biosolid PC contained significantly lower numbers of anaerobic bacteria $\left(1.1 \times 10^{4} \mathrm{CFU} \mathrm{g^{-1 }}\right)$ than the non-amended product $\left(2.0 \times 10^{4} \mathrm{CFU} \mathrm{g}^{-1}\right)$ (Table 1). Chitosan also significantly reduced the number of fungi from $1.0 \times 10^{3}$ CFU g ${ }^{-1}$ in biosolid $P$ to $7.5 \times 10^{2}$ CFU g $g^{-1}$ in biosolid PC. Counts of total aerobic bacteria and actinomycetes did not significantly differ within biosolids (Table 1).

\section{Sequencing of library clones}

Partial sequences of the 16S rDNA gene were obtained for 100 clones associated with biosolids $P$ and PC. Sequences associated with clones 20B and $70 \mathrm{~B}$ were considered as putative chimeras (Maidak et al. 2000) and were not further analyzed. BLAST algorithms from $\mathrm{NCBI}$ were used to align clone sequences with previously characterized genes from

Table 2. Phylogenetic groups associated with biosolids P and PC

\begin{tabular}{|c|c|c|c|}
\hline \multirow[b]{2}{*}{ Order } & \multirow[b]{2}{*}{ Genus } & \multicolumn{2}{|c|}{ Proportion of clones (\%) } \\
\hline & & Biosolid P & Biosolid PC \\
\hline \multirow[t]{3}{*}{ Xanthomonodales } & Stenotrophomonas & 26 & 28 \\
\hline & Xanthomonas & 3 & 4 \\
\hline & Thermomonas & 0 & 1 \\
\hline \multirow[t]{3}{*}{ Pseudomonadales } & Acinetobacter & 9 & 6 \\
\hline & Pseudomonas & 0 & 2 \\
\hline & Psychrobacter & 1 & 0 \\
\hline \multirow[t]{3}{*}{ Enterobacteriales } & Shigella & 1 & 0 \\
\hline & Photorabdus & 0 & 1 \\
\hline & Salmonella & 1 & 0 \\
\hline \multirow[t]{4}{*}{ Burkholderiales } & Comamonas & 2 & 7 \\
\hline & Bordetella & 1 & 0 \\
\hline & Acidovorax & 2 & 1 \\
\hline & Alcaligenes & 1 & 0 \\
\hline \multirow[t]{5}{*}{ Actinomycetales } & Brevibacterium & 3 & 4 \\
\hline & Arthrobacter & 4 & 4 \\
\hline & Terrabacter & 1 & 0 \\
\hline & Corynebacterium & 2 & 0 \\
\hline & Nocardiodes & 1 & 0 \\
\hline \multirow[t]{6}{*}{ Bacillales } & Ureibacillus & 4 & 4 \\
\hline & Bacillus & 5 & 10 \\
\hline & Caryophanon & 1 & 4 \\
\hline & Sporosarcina & 0 & 1 \\
\hline & Staphylococcus & 4 & 2 \\
\hline & Turicibacteraceae & 2 & 0 \\
\hline Clostridiales & Clostridium & 1 & 1 \\
\hline \multirow[t]{3}{*}{ Lactobacillales } & Globicatella & 0 & 2 \\
\hline & Tricochococcus & 1 & 0 \\
\hline & Enterococcus & 0 & 2 \\
\hline
\end{tabular}


the RDP database. A number of clones (21 in biosolid $P$ and 16 in biosolid PC) were associated with bacteria of unknown taxonomic identity, while respectively $77 \%$ and $84 \%$ of the clones from biosolid $\mathrm{P}$ and biosolid PC shared between 95 and $99 \%$ identity with the 16S rDNA gene of an identified bacterial strain.

\section{Phylogenetic analysis}

Table 2 presents the list of clones found in biosolids $P$ and $\mathrm{PC}$ that shared at least $95 \%$ similarity with a 16S rDNA sequence from a strain belonging to a characterized bacterial genus. In both biosolids, clones were associated with the following bacterial orders: Xanthomonodales, Pseudomonadales, Enterobacteriales, Burkholderiales, Actinomycetales, Bacillales, Clostridiales and Lactobacillales. Bacteria from the Xanthomonodales order represented the main phylogenetic group in both biosolids, and bacteria from the Stenotrophomonas genus were the most abundant. They accounted for 26 and $28 \%$ of $\mathrm{P}$ and $\mathrm{PC}$ biosolid clones, respectively. Some genera were similarly represented within both biosolids. This is the case for Arthrobacter, Ureibacillus and Clostridium.

However, chitosan appeared to induce change in the population of some bacterial genera (Table 2). For example, clones associated with the genus Bacillus doubled to reach $10 \%$ of the PC clones. Comamonas, which represented $2 \%$ of the biosolid $\mathrm{P}$ clones, accounted for $7 \%$ of the biosolid PC clones. Caryophanon represented 1 and $4 \%$ of the $P$ and $P C$ biosolid clones, respectively. Pseudomonas, Globicatella, Enterococcus, Thermomonas, Photorabdus and Sporsarcina, which were not detected in biosolid $\mathrm{P}$, were found in a proportion of 1 to $2 \%$ in biosolid PC. On the other hand, the addition of chitosan appeared to reduce the population of some other bacterial genera. For instance, the proportion of clones associated with the genera Acinetobacter and Staphyloccocus was reduced by about $50 \%$ in biosolid PC. Corynebacterium, which represented $2 \%$ of the biosolid $\mathrm{P}$ clone library, was not detected in biosolid PC.

The $16 \mathrm{~S}$ rDNA sequences of 21 and $16 \%$ of the clones from biosolids $\mathrm{P}$ and $\mathrm{PC}$, respectively, showed homology with uncultured bacteria for which a 16S rRNA gene sequence was deposited in the database. Table 3 presents the origin of the uncultured bacteria associated with the biosolid clones. Most of the uncultured bacteria originated from a farm environment, i.e. animal, manure or agricultural soil. The majority of the unidentified clones shared similarity with bacteria isolated from swine manure biofilms or from pig gastrointestinal tracts.

Table 3. Proportion of biosolid clones showing 16S rDNA sequence homology with sequences from uncultured bacteria

\begin{tabular}{|c|c|c|c|c|}
\hline \multirow[b]{2}{*}{ Uncultured bacterium } & \multirow{2}{*}{$\begin{array}{l}\text { Accession } \\
\text { number }^{1}\end{array}$} & \multirow[b]{2}{*}{ Origin } & \multicolumn{2}{|c|}{ Proportion of clones (\%) } \\
\hline & & & Biosolid P & Biosolid PC \\
\hline Actinobacterium EB1077 & DQ374451 & Pasture soil & 2 & 0 \\
\hline Bacterium SM-2 & DQ374452 & Swine manure biofilm & 6 & 6 \\
\hline$\beta$-proteobacterium AKYG862 & DQ374453 & $\begin{array}{l}\text { Farm soil adjacent to a silage } \\
\text { storage bunker }\end{array}$ & 1 & 0 \\
\hline Clone p-406-o3 & DQ374454 & Pig gastrointestinal tract & 1 & 0 \\
\hline Clone THM-10 & DQ374455 & Pig gastrointestinal tract & 2 & 1 \\
\hline Clone p-248-o5 & DQ374456 & Pig gastrointestinal tract & 2 & 1 \\
\hline Clone p-4936-6wbz & DQ374467 & Pig gastrointestinal tract & 0 & 1 \\
\hline Clone 2 & DQ374457 & Piglet gastrointestinal tract & 1 & 0 \\
\hline Clone D-66 & DQ374458 & $\begin{array}{l}\text { Teat canals of healthy } \\
\text { lactating bovines }\end{array}$ & 1 & 0 \\
\hline Clone B-85 & DQ374465 & $\begin{array}{l}\text { Teat canals of healthy } \\
\text { lactating bovines }\end{array}$ & 0 & 1 \\
\hline Clone GZKB112 & DQ374459 & Municipal solid waste landfill & 2 & 1 \\
\hline Clone TSBw02 & DQ374460 & $\begin{array}{l}\text { Polychlorinated dioxin } \\
\text { dechlorinating microcosm }\end{array}$ & 1 & 0 \\
\hline Bacterium DSSD95 & DO374461 & $\begin{array}{l}\text { Drinking water in a } \\
\text { distribution system }\end{array}$ & 1 & 0 \\
\hline Uncultured Acinetobacter & DQ374462 & $\begin{array}{l}\text { Ectoparasitic chewing lice of } \\
\text { pocket gophers }\end{array}$ & 2 & 0 \\
\hline Bacterium B24 & DQ374463 & Feedlot manure & 0 & 2 \\
\hline Clone sl2_505 & DQ374464 & Grassland soil & 0 & 1 \\
\hline$\alpha$-proteobacterium Bigi7 & DQ374466 & Industrial waste gas biofilter & 0 & 1 \\
\hline Clone A-3L & DQ374468 & Anaerobic swine lagoon & 0 & 1 \\
\hline
\end{tabular}

'These sequences exhibit more than 95\% homology with the 16S rDNA sequences of biosolid clones. 
Table 4. Effect of potato seed treatments consisting of dehydrated pork manure by-product amended or not with chitosan on common scab of potato

\begin{tabular}{lccccc}
\hline & \multicolumn{2}{c}{ L'Assomption (2004) } & & \multicolumn{2}{c}{ Lavaltrie (2005) } \\
\cline { 2 - 3 } \cline { 5 - 6 } $\begin{array}{l}\text { Potato seed } \\
\text { treatment }\end{array}$ & $\begin{array}{c}\text { Disease } \\
\text { incidence } \\
(\%)^{1}\end{array}$ & $\begin{array}{c}\text { Yield } \\
(\mathrm{kg} / \mathrm{plot})^{2}\end{array}$ & $50.4 \mathrm{a}$ & $\begin{array}{c}\text { Disease } \\
\text { incidence } \\
(\%)^{1}\end{array}$ & $\begin{array}{c}\text { Yield } \\
(\mathrm{kg} / \mathrm{plot})^{2}\end{array}$ \\
\hline Talc (control) & $57 \mathrm{~b}$ & & $20 \mathrm{a}$ & $24.8 \mathrm{a}$ \\
Biosolid P & $76 \mathrm{c}$ & $48.7 \mathrm{a}$ & $57 \mathrm{~b}$ & $26.4 \mathrm{a}$ \\
Biosolid PC & $49 \mathrm{a}$ & $58.6 \mathrm{a}$ & $22 \mathrm{a}$ & $23.6 \mathrm{a}$ \\
\hline
\end{tabular}

${ }_{1}^{1}$ Within a column, data followed by the same letter do not differ significantly $\left(P<0.05 ; \chi^{2}\right.$ test $)$.

${ }^{2}$ Within a column, data followed by the same letter do not differ significantly $(P<0.05$; LSD test).

\section{Effect of pork manure biosolid on common scab of potato}

Field assays were carried out over 2 consecutive yr and the effect of biosolids on common scab of potato was analyzed. As shown in Table 4, common scab was more severe in 2004 than in 2005 as indicated by the higher level of disease incidence $(57.0$ versus $19.5 \%)$ in the control treatment. A seed treatment with biosolid $\mathrm{P}$ increased the amount of diseased tubers by a factor of 1.33 and 2.85 in 2004 and 2005, respectively. The addition of chitosan in biosolid $P$ suppressed the stimulating effect of this seed treatment on common scab disease. Biosolid PC used as seed treatment reduced by approximately $15 \%$ the level of common scab in 2004 compared with the control treatment. Such a reduction was not observed in 2005, but common scab incidence was brought back to a level comparable to that of the control treatment $\left(P>0.05, \chi^{2}\right.$ test) (Table 4). Application of biosolids $P$ and $P C$ as seed treatments did not significantly affect potato yield.

\section{DISCUSSION}

Microbial analysis of the biosolids used in this study revealed the origin of this organic material. Indeed, the 16Sr DNA sequences identified from the biosolid microbial community were often associated with those of microorganisms previously isolated from manure (Stenotrophomonas, Bacillus and Acinetobacter) (Laukovà 2001; Lueng and Topp 2001; Sasaki et al. 2005; Snell-Castro et al. 2005) or with uncultured bacteria from manure or pig microflora. The fact that a considerable proportion of clones in the biosolids (21 and 16\% in biosolids $\mathrm{P}$ and $\mathrm{PC}$, respectively) could not be associated with a bacterium of known taxonomic identity shows the need for further research on the microbiology of manure and manure by-products. Marti et al. (2009) also reported that a high proportion of 16S rRNA gene sequences found in manure presented a low level of similarity to sequences in databases.

Previous studies using culture-dependent methods established the fact that the main taxonomic groups found in swine manure are Gram-positive anaerobic bacteria, such as Clostridium, Lactobacillus and Streptoccoccus (Whitehead and Cotta 2001). Although bacteria belonging to the Clostridiales and
Lactobacillales orders were also found in biosolids, they did not represent a high proportion of the clones. The bacterial composition of the biosolids and the raw manure appeared to differ considerably, suggesting that the biological treatment of pork manure modified considerably the microflora of the product. However, data obtained from culture-dependent and culture-independent methods are not always congruent (Dobrovol'skaya et al. 2001; Zhang et al. 2009). One could therefore not exclude the possibility that differences between the microbial composition of swine manure (Whitehead and Cotta 2001) and biosolids (this work) are a consequence of the experimental procedure used in both studies.

The data presented here suggest that Gramnegative bacteria belonging to the Stenotrophomonas genus prevailed in the biosolids. Stenotrophomonas is a widespread bacterium in the environment. It was found in the soil, on plant surfaces as well as in aquatic environments (Denton and Kerr 1998). Stenotrophomonas strains also represent a bacterial group of agronomic importance, and they were found to be associated with the rhizosphere of numerous plant species (Berg 1996; Berg et al. 1996; Lottmann et al. 1999).

Members of the genera Acinetobacter and Bacillus also appeared to be predominant bacteria in biosolids. Bacteria of the Acinetobacter genus are widely distributed in nature and could be isolated from soil, water and human skin (Jawad et al. 1998). In activated sludge systems, they participated in the removal of phosphorus (Beachman et al. 1990; Mino et al. 1998). In these applications, some authors have even established that Acinetobacter was the primary biological agent responsible for phosphate removal (Auling et al. 1991; Wagner et al. 1994). The presence of an important amount of phosphate in manure could thus explain the presence of these bacteria in the by-products of the manure transformation process. The fact that anaerobic and aerobic conditions alternated during the biological treatment of swine manure could also have favoured Acinetobacter. These conditions have been reported to promote the growth of microorganisms accumulating phosphates (Grady et al. 1999).

Although Bacillus strains have frequently been isolated from manure (Lueng and Topp 2001; Ouwerkerk and Klieve 2001; Snell-Castro et al. 2005), they did 
represent a low proportion of the manure microbial colonizers. The transformation process used to obtain the biosolids may have exposed manure microorganisms to dryness and high temperatures. These conditions could have introduced a positive selective bias for bacteria such as Bacillus species that produce heat-resistant spores.

Biosolids $\mathrm{P}$ and $\mathrm{PC}$ were compared for their microbial composition. The number of bacteria and actinomycetes colonizing the biosolids did not appear to be affected by the addition of chitosan, while the populations of both fungal organisms and anaerobic bacteria only slightly decreased in the presence of chitosan. This slight decrease might be attributed to the antimicrobial activity of chitosan. This polymer has been shown to be generally more toxic on fungi than on bacteria (Savard et al. 2002). The decrease in anaerobic bacteria population might confer an advantage to biosolid PC in agricultural practices. Anaerobic bacteria such as Eubacterium and Clostridium are the main contributors of volatile fatty acids associated with manure odor (Rappert and Müller 2005; Zhu 2000), while others are potential pathogens (Nervig et al. 1981). Few studies have reported the effect of chitosan on anaerobic bacteria and most of these focused on human pathogen or food spoilage bacteria. Inatsu et al. (2005) established that chitosan exhibited a bactericidal activity against $E$. coli, Salmonella enteritidis (Gaertner) Castellani \& Chalmers, Staphylococcus aureus Rosenbach and Listeria monocytogenes (Murray et al.) Pirie in fermented chinese cabbage. The 16S rDNA analysis carried out in this study suggest that the potential pathogenic bacteria usually found in manure, such as E. coli, Campylobacter and Salmonella (Sobsey et al. 2001), did not account for a high proportion of the biosolid microflora. Nevertheless, other potential human pathogens were detected in biosolid $\mathrm{P}(7 \%$ of the clones were associated with Samonella, Staphylococcus, Shigella and Bordetella), while no clone related to these genera was identified in biosolid PC. The growth of Shigella dysenteriae (Shiga) Castellani \& Chalmers, Salmonella typhimurium (Loeffer) Castellani \& Chalmers, and Staphylococcus aureus has previously been found to be inhibited in the presence of chitosan (Helander et al. 2001; Liu et al. 2001; Tsai et al. 2000). However, since the antimicrobial action of chitosan is influenced by intrinsic factors such as the degree of chitosan polymerization, the proportion of acetylated residues in the polymer and environmental conditions (Rabea et al. 2003), further analyses would be required to determine the antimicrobial activity of chitosan on potential pathogens present in both manure and biosolids.

While chitosan has a negative effect on some microbial groups, Bacillus and Comamonas prevailed in biosolid PC. The ability of several Bacillus and Comamonas strains to produce chitosanases (Choong Soo et al. 2005; Kurakake et al. 2000; Omumasaba et al. 2000) could explain their prevalence since chitosan would represent an additional carbon and nitrogen source for such chitosanolytic microorganisms.

The use of animal manure for potato crops is controversial since some authors have observed an increase in common scab incidence following soil amendment with manure (Blodgett 1940), while others have reported common scab suppression through manure amendment (Conn and Lazarovits 1999). These contradictory results might be explained by the complexity of the manure substrate (Conn and Lazarovits 1999). Even if biological treatments modifying the microbial composition of manure could also influence the properties of this organic material, our study reveals that manure solids could effectively contribute to common scab incidence.

When applied as seed treatment in 2004 and 2005, biosolid $\mathrm{P}$ significantly increased common scab incidence. The mechanisms linked to the stimulating effect of a local application of biosolid $P$ (seed treatment) on disease symptom development have yet to be elucidated. Biosolid $\mathrm{P}$ possibly brought nutrients or physicochemical conditions that conferred an advantage to the $S$. scabies population or that might contribute to a better colonization of the potato seed tubers by the S. scabies. Han et al. (2008) suggested that the soil population of common scab-inducing pathogens colonized seed potatoes at planting and modified root development. Alternatively, the microbial community of biosolid $P$ might contribute to the increased level of disease by competing with $S$. scabies antagonistic agents that colonize soil and potato organs (Liu et al. 1995) or by secreting compounds that stimulate toxin biosynthesis in $S$. scabies (Agbessi et al. 2003).

The addition of chitosan to biosolid $P$ cancelled the stimulating effect of this product on common scab incidence. In 2005, biosolid PC even decreased common scab incidence by $14 \%$ when compared with the control treatment. One could postulate that chitosan may contribute to disease suppression by eliciting plant defence mechanisms (Benhamou et al. 1994) or by inhibiting the growth of the pathogen. This is unlikely the case since Jobin et al. (2005) showed that chitosan beads were degraded within $1 \mathrm{wk}$ after their addition to a soil substrate. The manure by-product used in this study was incubated in the presence of chitosan for over $1 \mathrm{wk}$ before application on potato tubers.

In other studies, a soil amendment with chitinous material (Vruggink 1970) or shrimp waste-based composts was shown to both stimulate the growth of Gram-positive bacteria and to reduce common scab incidence (Côté et al. 2001). Interestingly, some microorganisms antagonistic to $S$. scabies were able to grow on chitosan as carbon and nitrogen sources (Beauséjour et al. 2003). Chitosan amendment could therefore have modified the microflora of biosolid $\mathrm{P}$ to promote bacterial populations antagonistic to $S$. scabies. The increase in Bacillus population, a genus known to comprise numerous chitosanase producers (Kurakake et al. 2000; Omumasaba et al. 2000) as well as biocontrol agents of common scab (Han et al. 2005; Sturz et al. 2004), could explain why biosolid PC annihilated the stimulating effect of the non-amended manure by-product on common scab.

Several studies have demonstrated that chitosan contributes to plant protection (Bautista-Banos et al. 2006) by stimulating plant defence mechanisms (Benhamou et al. 1994) and by inhibiting the growth 
of several plant pathogens (Rabea et al. 2003), but as showed here, chitosan amendment could also modify the microbial communities of an agricultural product. Such an amendment could promote the innocuity or the biocontrol efficiency of organic fertilizers, plant growth substrates and seed treatments.

\section{ACKNOWLEDGEMENTS}

This work was supported by grants from the Conseil de recherches en pêche et en agroalimentaire du Québec (CORPAQ) and the Natural Sciences and Engineering Research Council (NSERC) of Canada. We also acknowledge the contribution of Envirogain. We thank M. Lapointe for technical assistance and S. Roy for a critical review of the manuscript.

\section{REFERENCES}

Agbessi, S., J. Beauséjour, C.V. Déry, and C. Beaulieu. 2003. Antagonistic properties of two recombinant strains of Streptomyces melanosporofaciens obtained by intraspecific protoplast fusion. Appl. Microbiol. Biotechnol. $62: 233-238$

Auling, G., F. Pilz, H.J. Busse, S. Karrasch, M. Streichan, and G. Schon. 1991. Analysis of the polyphosphate-accumulating microflora in phosphorus-eliminating, anaerobic-aerobic activated sludge systems by using diaminopropane as a biomarker for rapid estimation of Acinetobacter spp. Appl. Environ. Microbiol. 57 : 3585-3592.

Bailey, K.L., and G. Lazarovits. 2003. Suppressing soil-borne diseases with residue management and organic amendments. Soil Tillage Res. $72: 169-180$.

Bautista-Banos, S., A.N. Hernandez-Lauzardo, and N.G. Velazquez-del Valle. 2006. Chitosan as a potential natural compound to control pre and postharvest diseases of horticultural commodities. Crop Prot. 25 : 108-118.

Beachman, A.M., R.J. Seviour, K.C. Lindrea, and I. Livingston. 1990. Genospecies diversity of Acinetobacter isolates obtained from a biological nutrient removal pilot plant of a modified UCT configuration. Water Res. 24 : 2329.

Beauséjour, J., N. Clermont, and C. Beaulieu. 2003. Effect of Streptomyces melanosporofaciens strain EF-76 and chitosan on common scab of potato. Plant Soil $256: 463-468$.

Benhamou, N., P.J. Lafontaine, and M. Nicole. 1994. Induction of systemic resistance to Fusarium crown and root rot in tomato plants by seed treatment with chitosan. Phytopathology 84 : 1432-1444.

Berg, G. 1996. Rhizobacteria of oilseed rape antagonistic to Verticillium dahliae. J. Plant Dis. Prot. $103:$ 20-30.

Berg, G., P. Marten, and G. Ballin. 1996. Stenotrophomonas maltophilia in the rhizosphere of oilseed rape-occurence, characterization and interaction with phytopathogenic fungi. Microbiol. Res. 151 : 19-27.

Blodgett, F.M. 1940. A second report on the effect of agronomic practices on the incidence of Rhizoctonia and scab of potatoes. Am. Potato J. $17: 290-295$.

Choong Soo, Y., D. Amakata, Y. Matsuo, H. Matsuda, and M. Kawamukai. 2005. New chitosan-degrading strains that produce chitosanases similar to choA of Mitsuaria chitosanitabida. Appl. Environ. Microbiol. 71 : 5138-5144.

Conn, K.L., and G. Lazarovits. 1999. Impact of animal manures on verticillium wilt, potato scab, and soil microbial populations. Can. J. Plant Pathol. 21 : 81-92.

Côté, N., R. Hogue, C. Beaulieu, and R. Brzezinski. 2001. Suppressive effect of chitin waste-based composts on common scab of potato. Pages 155-161 in R.A.A. Muzzarelli (ed.), Chitin Enzymology. Atec Edizioni, Ancona, Italy.
Denton, M., and K.G. Kerr. 1998. Microbiological and clinical aspects of infections associated with Stenotrophomonas maltophilia. Clin. Microbiol. Rev. $11: 7-80$.

Dobrovol'skaya, T.G., L.V. Lysak, G.M. Zenova, and D.G. Zvyagintsev. 2001. Analysis of soil bacterial diversity: methods, potentiality, and prospects. Microbiology 70 : 119-132.

Gorissen, A., L.S. van Overbeek, and J.D. van Elsas. 2004. Pig slurry reduces the survival of Ralstonia solanacearum biovar 2 in soil. Can. J. Microbiol. 50 : 587-594.

Grady, C.P.L., G.T. Daigger, and H.C. Lim. 1999. Biological wastewater treatment, 2nd ed. Marcel Dekker Inc., New York, USA. $1076 \mathrm{p}$.

Hadar, Y., R. Mandelbaum, and B. Gorodecki. 1992. Biological control of soilborne plant pathogens by suppressive compost. Pages 79-83 in E.S. Tjamos, G.C. Papavizas, and R.J. Cook (eds.), Biological Control of Plant Diseases. Plenum Press, New York, USA.

Han, J.S., J.H. Cheng, T.M. Yoon, J. Song, A. Rajkarnikar, W.G. Kim, I.D. Yoo, Y.Y. Yang, and J.W. Suh. 2005. Biological control agent of common scab disease by antagonistic strain Bacillus sp. sunhua. J. Appl. Microbiol. 99 : 213-221.

Han, L., P. Dutilleul, S.O. Prasher, C. Beaulieu, and D.L. Smith. 2008. Assessment of common scab-inducing pathogen effects on potato underground organs via computed tomography scanning. Phytopathology 59 : 42594270.

Helander, I.M., E.-L. Nurmiaho-Lassila, R. Ahvenainen, J. Rhoades, and S. Roller. 2001. Chitosan disrupts the barrier properties of the outer membrane of Gram-negative bacteria. Int. J. Food Microbiol. 71 : 235-244.

Hill, J., and G. Lazarovits. 2005. A mail survey of growers to estimate potato common scab prevalence and economic loss in Canada. Can. J. Plant Pathol. 27 : 46-52.

Hooker, W.J. 1981. Common scab. Pages 33-34 in W.J. Hooker (ed.), Compendium of Potato Diseases. APS Press, St. Paul, MN, USA.

Huber, D.M., and R.D. Watson. 1970. Effect of organic amendment on soilborne plant pathogens. Phytopathology $60: 22-26$.

Inatsu, Y., M.L. Bari, S. Kawasaki, and S. Kawamoto. 2005. Effectiveness of some natural antimicrobial compounds in controlling pathogen or spoilage bacteria in lightly fermented chinese cabbage. J. Food Sci. 70 : M393-M397.

Jawad, A., A.M. Snelling, J. Heritage, and P.M. Hawkey. 1998. Comparaison of ARDRA and recA-RFLP analysis for genomic species identification of Acinetobacter spp. FEMS Microbiol. Lett. 165 : 357-362.

Jobin, G., G. Couture, C. Goyer, R. Brzezinski, and C. Beaulieu. 2005. Streptomycete spores entrapped in chitosan beads as a novel biocontrol tool against common scab of potato. Appl. Microbiol. Biotechnol. 68 : 104-110.

Keinath, A.P., and R. Loria. 1989. Management of common scab of potato with plant nutrients. Pages 152-166 in A.W Engelhard (ed.), Soilborne Plant Pathogens: Management of Disease with Macro- and Microelements. APS Press, St. Paul, MN, USA.

Kurakake, M., S. You, K. Nakagawa, M. Sugihara, and T. Komaki. 2000. Properties of chitosanase from Bacillus cereus S1. Curr. Microbiol. 40 : 6-9.

Kurita, K. 2006. Chitin and chitosan: functional biopolymers from marine crustaceans. Mar. Biotechnol. 8 : 203-226.

Kutchma, A.J., M.A. Roberts, D.B. Knaebel, and D.L. Crawford. 1998. Small-scale isolation of genomic DNA from streptomyces mycelia or spores. Biotechniques 24 : 452-457.

Kwok, O.C.H., P.C. Fahy, H.A.J. Hoitink, and G.A. Kuter. 1987. Interactions between bacteria and Trichoderma hamatum in suppression of Rhizoctonia damping-off in bark compost media. Phytopathology 77 : 1206-1212. 
Labrie, C., P. Leclerc, N. Côté, S. Roy, R. Brzezinski, R. Hogue, and C. Beaulieu. 2001. Effect of chitin waste-based composts produced by two-phase composting on two oomycete plant pathogens. Plant Soil 235 : 27-34.

Lambert, D.H., and R. Loria. 1989. Streptomyces scabies sp. nov., nom. rev. Int. J. Syst. Bacteriol. 39 : 387-392.

Laukovà, A. 2001. Effect of enterocins CCM4231 and V24 on the cells of environmental isolates Acinetobacter spp. Acta Vet. Brno $70:$ 473-477.

Liu, D., N.A. Anderson, and L.L. Kinkel. 1995. Biological control of potato scab in the field with antagonistic Streptomyces scabies. Phytopathology 85 : 827-831.

Liu, X.F., Y.L. Guan, D.Z. Yang, Z. Li, and K. de Yao. 2001. Antibacterial action of chitosan and carboxymethylated chitosan. J. Appl. Polym. Sci. 79 : 1324-1335.

Lottmann, J., H. Heuer, K. Smalla, and G. Berg. 1999. Influence of transgenic T4-lysosyme-producing plants on beneficial plant-associated bacteria. FEMS Microbiol. Ecol. 29 : 365-377.

Leung, K, and E. Topp. 2001. Bacterial community dynamics in liquide swime manure during storage: molecular analysis using DGGE/PCR of $16 \mathrm{~S}$ rDNA. FEMS Microbiol. Ecol. 38 : 169-177.

Madden, T.L., R.L. Tatusov, and J. Zhang. 1996. Application of network BLAST server. Methods Enzymol. 266 : 131 134.

Maidak, B.L., J.R. Cole, T.G. Lilburn, C.T. Parker Jr., P.R. Saxman, J.M. Stredwick, G.M. Garrity, B. Li, G.J. Olsen, S. Pramanik, T.M. Schmidt, and J.M. Tiedje. 2000. The RDP (Ribosomal Database Project) continues. Nucleic Acids Res. $28: 173-174$

Marti, R., P. Dabert, and A.M. Pourcher. 2009. Pig manure contamination marker selection based on the influence of biological treatment on the dominant fecal group. Appl. Environ. Microbiol. 75 : 4967-4974.

Mino, T., M.C.M. Van Loosdrecht, and J.J. Heijnen. 1998. Microbiology and biochemistry of the enhanced biological phosphate removal process. Water Res. 32 : 31933207.

Nervig, R.M., S.E. Maloy, K.D. Claud, and D.R. Kolbe. 1981. Clostridium septicum infection in cattle in the United States. J. Am. Vet. Med. Assoc. $179: 479$.

Omumasaba, C.A., N. Yoshida, Y. Sekiguchi, K. Kariva, and K. Ogawa. 2000. Purification and some proprieties of novel chitosanase from Bacillus subtilis KH1. J. Gen. Appl. Microbiol. 46 : 19-27.

Osunlaja, S.O. 1990. Effect of organic soil amendments on the incidence of stalk rot of maize. Plant Soil $127: 237$ 241.

Ouwerkerk, D., and A.V. Klieve. 2001. Bacterial diversity within feedlot manure. Anaerobe 7 : 59-66.

Pennypacker, B.W. 1989. The role of mineral nutrition in the control of verticilium wilt. Pages 32-45 in A.W. Engelhard (ed.), Soilborne Plant Pathogens: Management of Disease with Macro- and Microelements. APS Press, St. Paul, MN, USA.

Prévost, K., G. Couture, J.W. Shipley, R. Brzezinski, and C. Beaulieu. 2006. Effect of chitosan and a biocontrol streptomycete on field and potato tuber bacterial communities. BioControl $51: 533-546$.

Rabea, E.I., M.E.T. Badawy, C.V. Stevens, G. Smagghe, and W. Steurbaut. 2003. Chitosan as antimicrobial agent: Applications and mode of action. Biomacromolecules 4 : 1457-1465.
Rappert, S., and R. Müller. 2005. Odor compounds in waste gas emissions from agricultural operations and food industries. Waste Manag. 25 : 887-907.

Sambrook, J., and D.W. Russel. 2001. Molecular Cloning: A Laboratory Manual, 3rd Ed. Cold Spring Harbor Laboratory Press, New York, USA.

Sasaki, H., H. Yano, T. Sasaki, and Y. Nakai. 2005. A survey of ammonia-assimilating micro-organisms in cattle manure composting. J. Appl. Microbiol. 99 : 1356-1363.

Savard, T., C. Beaulieu, I. Boucher, and C.P. Champagne. 2002. Antimicrobial action of hydrolyzed chitosan against spoilage yeasts and lactic acid bacteria of fermented vegetables. J. Food Protect. 65 : 828-833.

Schröder, J. 2005. Revisiting the agronomic benefits of manure: a correct assessment and exploitation of its fertilizer value spares the environment. Bioresour. Technol. $96: 253-261$.

Snell-Castro, R., J.-J. Godon, J.-P. Delgenès, and P. Dabert. 2005. Characterisation of the microbial diversity in a pig manure storage pit using small subunit rDNA sequence analysis. FEMS Microbiol. Ecol. 52 : 229-242.

Sobsey, M.D., L.A. Khatib, V.R. Hill, E. Alocilja, and S. Pillai. 2001. Pathogens in animal wastes and the impacts of waste management practices on their survival, transport and fate. In White Papers on Animal Agriculture and the Environment. Midwest Plan Service (MWPS), lowa State University, Ames, USA.

Sturz, A.V., D.A.J. Ryan, A.D. Coffin, B.G. Matheson, W.J. Arsenault, J. Kimpinski, and B.R. Christie. 2004 Stimulating disease suppression in soils: sulphate fertilizers can increase biodiversity and antibiosis ability of root zone bacteria against Streptomyces scabies. Soil Biol. Biochem. 36 : 343-352.

Tsai, G.-J., Z.Y. Wu, and W.H. Su. 2000. Antibacterial activity of a chitooligosaccharide mixture prepared by cellulase digestion of shrimp chitosan and its application to milk preservation. J. Food Protect. $63:$ 747-752.

Vruggink, H. 1970. The effect of chitin amendment on actinomycetes in soil and on the infection of potato tubers by Streptomyces scabies. Neth. J. Plant Pathol. 76 : 293-295.

Wagner, M., R. Erhart, W. Manz, R. Amann, H. Lemmer, D. Wedi, and K.H. Schleifer. 1994. Development of an rRNAtargeted oligonucleotide probe specific for the genus Acinetobacter and its application for in situ monitoring in activated sludge. Appl. Environ. Microbiol. 60 : 792-800.

Whitehead, T.R., and M.A. Cotta. 2001. Characterisation and comparison of microbial populations in swine faeces and manure storage pits by $16 \mathrm{~S}$ rDNA gene sequence analyses. Anaerobe 7 : 181-187.

Whitehead, T.R., and M.A. Cotta. 2004. Isolation and identification of hyper-ammonia producing bacteria from swine manure storage pits. Curr. Microbiol. 48 : 20-26.

Zhang, L., Z. Xu, and B. Patel. 2009. Culture-dependent and culture-independent microbial investigation of pine litters and soil in subtropical Australia. J. Soils Sediments $9: 148-160$.

Zhu, J. 2000. A review of microbiology in swine manure odor control. Agric. Ecosyst. Environ. 78 : 93-106. 